\title{
Is Forward-Looking Financial Disclosure Really Informative? Evidence from UK Narrative Statements
}

\author{
Ahmed Hassanein** \\ Plymouth University, UK \\ Mansoura University, Egypt \\ Ahmed.hassanein@plymouth.ac.uk \\ Khaled Hussainey*/** \\ Plymouth University, UK \\ Ain Shams University, Egypt \\ khaled.hussainey@plymouth.ac.uk
}

\section{Correspondence Details}

* Correspondence should be addressed to Professor Khaled Hussainey, 405H Cookworthy Building, Accounting and Finance Division, Plymouth Management School, Plymouth University, Plymouth, PL4 8AA, UK. E-mail: khaled.hussainey@ plymouth.ac.uk.

\section{ACKNOWLEDGMENTS}

** We would like to thank Professor Brian M Lucey (The Editor of IRFA) and an anonymous referee for helpful comments and suggestions. We also thank Dr. Ven Tauringana, the organiser of the $12^{\text {th }}$ Workshop on Accounting and Finance at Bournemouth University (September 2014) and the review committee of the $38^{\text {th }}$ EAA Annual Congress at Strathclyde University (April 2015) for their useful comments. Ahmed Hassanein appreciatively acknowledges the financial support of the Ministry of Higher Education and Mansoura University in Egypt for funding this study. 


\title{
Is Forward-Looking Financial Disclosure Really Informative? Evidence from UK Narrative Statements
}

\begin{abstract}
:
Forward-looking financial disclosure (FLFD) is potentially uninformative if it does not change from the previous year, especially after a significant change in firm performance. This study aims to examine whether and to what extent FLFD is changed in response to changes in firm performance. Then, it investigates the effect of such change in FLFD on firm value. The study uses a sample of UK narrative statements over the period from 2005 to 2011. It finds an association between change in FLFD and change in firm earnings performance. However, it finds weak evidence that firms with larger changes in earnings performance are likely to change their FLFD more than those with smaller performance changes. In addition, when we distinguish between well-performing and poorly performing firms, it finds that the change in FLFD is more positively associated with poorly performing firms compared to well-performing firms. Finally, the change in FLFD has no effect on the value of well-performing firms, while, it negatively affects poorly performing firms. The results suggest that forwardlooking financial information in UK narratives contains some relevant information about firm performance. However, it neither affects the value of well-performing firms nor enhances investors' valuation of poorly performing firms.
\end{abstract}

Keywords: Narrative Reporting; OFR; Forward-Looking Financial Disclosure; Firm Performance; Firm Value 


\section{INTRODUCTION}

Narrative reporting in annual reports complements financial statements and provides a channel for managers to convey textual information about their firms to market participants (Merkley, 2014). Nonetheless, market participants analyse narratives when making their decisions to bridge the gap between financial statements amounts and the economic reality of firms' performance (Feldman, Govindaraj, Livnat, \& Segal, 2010; Merkley, 2014). Recently, the International Accounting Standard Board (IASB) has worried about how informative narrative information is and has advised firms to avoid providing boilerplate disclosures. It is argued that "management should avoid generic disclosures that do not relate to the practices and circumstances of the entity and immaterial disclosures that make the more important information difficult to find" (IFRS, 2010, P. 12).

A natural question is whether narratives have informational content or simply boilerplate disclosures (i.e., standard disclosures with little firm-specific content). Narrative statements might not be as informative as intended for several reasons. First, managers have flexibility in choosing the breadth and depth of disclosed information. Accordingly, after considering the costs of preparing long narrative document, managers may simply use the previous year's narrative statements as templates for current and future years (Brown \& Tucker, 2011). Second, the qualitative nature of narratives makes them difficult to be audited and, therefore, many include substantial boilerplate disclosures, generic language, and immaterial details (Li, 2010a).

The Operating and Financial Review (OFR) is a key narrative reporting medium recommended by the Accounting Standard Board (ASB) for financial reporting in the United Kingdom (UK). It aims to provide analysis of a business through the eyes of the board of directors (ASB, 2005; ASB, 2006). The ASB recommends the analysis of the business in OFR statements to have a forward-looking orientation (ASB, 2005; ASB, 2006). This information would help investors to assess firms' past and current financial performance, and to predict future earnings (Hussainey, Schleicher, \& Walker, 2003).

In essence, a document that is similar to the previous year's version does not reveal considerable new information. This study uses change in FLFD in OFR statements over years to answer two research questions. First, whether and to what extent do firms' managers change FLFD in response to change in firms' current performance, if they do at all? Second, do investors respond to information revealed by change in FLFD? If FLFD level is changed 
(updated) in response to change in firm performance, it will include some informational content about firm performance and, thus, offers relevant information for investors.

The study considers change in FLFD in the UK for the following. The UK provides a unique context to analyse the FLFD. In the UK, FLFD is qualitative in nature and is not immediately verifiable or auditable (Wang \& Hussainey, 2013; Athanasakou \& Hussainey, 2014). This nature might encourage firm managers to use the previous year's FLFD as a template from year to year. The change in FLFD from the previous year reveals considerable new information that reflects change in the business environment. For instance, Muslu, Radhakrishnan, Subramanyam, and $\operatorname{Lim}(2011$, P. 10) argue that "a firm that is planning to expand operations overseas or introduce new product lines will add narratives on how initial setup will proceed". As such, the additional narratives are free of boilerplate disclosures and are more likely to indicate changes in the business environment. Furthermore, Merkley (2014) argues that for narrative reporting to perform its function, managers must be willing to change it based on changing financial performance of a firm.

This paper offers three contributions. First, it contributes to the body of knowledge on methodological developments in both measurement of FLFD and the estimation method in the empirical tests. Unlike prior research on forward-looking disclosure in UK narratives (e.g., Hussainey et al., 2003; Schleicher, Hussainey, \& Walker, 2007; Wang \& Hussainey, 2013), the study uses change in FLFD rather than their respective levels. Adopting change measure can better capture new information that is free of boilerplate statements and reflects change in the business environment (Muslu et al., 2011). In addition, this method mitigates the problem of endogeneity $(\mathrm{Li}, 2010 \mathrm{~b})$ and provides more robust results (Feldman et al., 2010); it also alleviates the measurement noise due to repetitive statements (Muslu et al., 2011). Furthermore, the study uses the OLS regression with robust standard error clustered by firm to mitigate the residual dependence problems caused by time effect (heteroskedasticity) and firm effect (auto-correlation). This estimation method accounts for the residual dependency problems frequently neglected in market-based accounting research (Gow, Ormazabal, \& Taylor, 2010).

Second, to the best of our knowledge, this is the first UK evidence that examines the extent to which firms change their FLFD from the previous year in response to change in performance. The study finds an association between change in firms' earnings performance and change in FLFD. It, however, finds evidence that firms with larger changes in earnings 
performance are likely to change their FLFD more than those with smaller performance changes. Furthermore, the change in FLFD is more positively associated with poorly performing firms compared to well-performing firms. Given that IASB concerns about the informativeness of narrative reporting, this study provides fresh evidence that FLFD in UK narratives contains some information about firm performance.

Third, prior empirical research assesses the value relevance of forward-looking statements in the UK narratives for predicting firms' future earnings (e.g., Hussainey et al., 2003; Schleicher et al., 2007; Wang \& Hussainey, 2013). This study extends the literature on the infomativeness of FLFD by examining the effect of the change in these statements on firm value. The findings indicate that FLFD neither affects the value of well-performing firms nor enhances investors' valuation of poorly performing firms. These findings add to our understanding on the usefulness of forward-looking information in narrative reporting.

The reminder of the paper proceeds as follows. Section 2 discusses the theoretical framework; it draws on the relevant theories, and literature to formulate the research hypotheses. Section 3 details the research design. Section 4 presents the findings. Section 5 introduces further analysis and a robustness check. Section 6 concludes.

\section{THEORITICAL FRAMEWORK}

\subsection{Theories}

Managers' decision to change FLFD over years is based on 1) the likelihood that managers have new information to disclose relative to the prior year, and 2) the costs of including more or less information in the narrative document. Therefore, the theoretical prediction is based on the following theories:

\subsubsection{Managers' incentive theories}

Managers' incentives to change narrative reporting could be explained through agency and signalling theories (Beyer, Cohen, Lys, \& Walther, 2010).

2.1.1.1 Agency theory: Managers with new information relative to the prior year may disclose it voluntarily to reduce information asymmetry and agency costs. When performance declines relative to the prior year, owners demand more information to better 
assess the uncertainty of future cash flow and, in turn, managers provide more information (e.g., forward-looking information).

2.1.1.2 Signalling theory: Managers with good news disclose this information voluntarily to signal their good news to avoid being pooled with managers of bad news. Furthermore, managers with bad news information (e.g., losses) may disclose it voluntarily to signal their capabilities and strengths to eliminate losses in the future.

\subsubsection{Cost of disclosure theories}

Managers' decision to change disclosure over years depends on the costs of including more or less information. These costs include:

2.1.2.1 Direct costs: On one hand, firms may have enough resources to cover the direct costs of disclosure (e.g., preparation costs); therefore, they are likely to update their disclosure over years. On the other hand, companies may simply cut and paste from previous years' disclosures in order to save preparation costs.

2.1.2.2 Political costs: Watts and Zimmerman (1978) argue that politically visible firms are likely to disclose information voluntarily. They are likely to update their disclosure regularly to limit their boilerplate disclosures to avoid the political costs of being perceived as being ambiguous.

2.1.2.3 Proprietary costs: This represents competitive disadvantage, because the extension in disclosing information by companies leads to additional information to be used by their rivals (Radebaugh \& Gray, 1997). Therefore, proprietary cost of disclosure may influence managers to avoid disclosing information that may help their competitors.

2.1.2.4 Litigation costs: Healy and Palepu (2001) argue that litigation costs have two great effects on companies' disclosure decision. First, lawsuits against companies for their insufficient disclosure may be an incentive for them to increase their disclosure. Second, litigation costs can reduce managers' incentives to provide narrative disclosure.

\subsection{Literature and hypotheses development}

This section reviews the two strands of the literature that are relevant to the current study and then we formulate the research hypotheses. The first strand relates to the association 
between change in firm performance and change in FLFD. The second focuses on investors' response to change in FLFD.

\subsubsection{Change in FLFD and change in firm performance}

The association between disclosure and performance could be hypothesised either positively or negatively. A positive association may be explained on the basis that managers of profitable firms tend to provide more discussion and analysis about their performance to signal their favourable results to investors. A negative association may be hypothesised on the basis that information asymmetry increases as performance decreases (Rogers \& Van Buskirk, 2009). Hayn (1995) argues that as earnings performance decreases, the earnings signal becomes noisier and the reported disclosure becomes less predictive of future performance. Thus, investors demand more information to better assess the uncertainty of future cash flows and, in turn, managers provide more discussion and analysis.

Literature on the relationship between performance and FLFD reports mixed results. Miller and Piotroski (2002), for example, find a positive association between performance and forward-looking information. On the other hand, Hussainey and Al-Najjar (2011) and Wang and Hussainey (2013) find a negative association between profit-making firms and forwardlooking disclosure. In addition, Schleicher et al. (2007) find that loss-making firms provide more relevant forward-looking information to investors than profit-making firms. Despite the above-mentioned research, to what extent FLFD is changed from the previous year is largely unexamined. FLFD is a qualitative soft talk (vs. hard facts) and is not verifiable or auditable. This nature may encourage managers of firms to use the previous year's FLFD as templates from year to year.

A change in a firm performance reveals considerable new information. This suggests that managers do have information to disclose to investors. Besides, managers of firms have incentives to disclose and update disclosure in response to changes in performance to reduce information asymmetry. Moreover, prior studies (e.g., Lang \& Lundholm, 1993; Miller, 2002; Merkley, 2014) suggest that change in the level of disclosure is associated with change in firm performance.

In a recent paper, Brown and Tucker (2011) find that firms with larger changes in their economic environment change their narratives more than those with smaller economic changes. Consequently, if managers follow the spirit of OFR statements, we expect them to 
provide discussion and analysis of firms' performance with a forward-looking orientation, and update their discussions over years in response to changes in performance. Furthermore, firms' managers with larger changes in their performance are expected to change their narratives more than those with smaller performance changes. Therefore, the following hypotheses are set:

\section{H1a: A positive association exists between change in firm performance and change in FLFD.}

\section{H1b: Firms with larger changes in their performance are likely to change their FLFD more than those with smaller performance changes.}

In this section, the change in firm performance is held constant to examine the factors that may drive managers to change FLFD. These factors are used to test the validity of the disclosure change score. Based on relevant literature, these factors are firm size, competitive environment, litigious environment, managerial ownership, and auditor type.

Firm size: Firm size is expected to be positively associated with change in FLFD for the following reasons. First, consistent with signalling theory, large firms are under pressure to provide relevant information to their financial analysts (Iatridis, 2008). Second, large firms are politically visible and tend to update their disclosure regularly to limit boilerplate narratives to avoid the political costs of being perceived as being ambiguous. Third, large firms are able to afford the preparation costs of narrative document (Lang \& Lundholm, 1993) or small firms might be more likely to cut and paste narratives from previous year in order to save preparation costs. Therefore, the study hypothesises that:

\section{H2a: A positive association exists between firm size and change in FLFD.}

Competitive environment: Verrecchia (1983) argues that when proprietary costs exist, information is withheld. Consistently, managers' incentives to disclose additional information appear to be sensitive to the nature of competition (Healy \& Palepu, 2001). Empirically, Brown and Tucker (2011) find that firms facing more competition are less likely to change their narrative reporting in MD\&A and, therefore, provide less informative narrative disclosure. Hence, it may be expected that firms in a more competitive environment - where preparatory costs are high - are less likely to provide informative future-oriented information. Consequently, these firms are less likely to change their FLFD over years. Therefore, we formulate the following hypothesis: 


\section{H2b: A negative association exists between competitive environment and change in FLFD.}

Litigious environment: Litigation is costly and firms have an interest in adopting policies of disclosure that reduce litigation costs (Lowry, 2009). On one hand, firms in more litigious environment are expected to update their FLFD over years in order to avoid the claim that they withhold relevant information from the market, which limits the potential litigation costs (Cox, Hillman, \& Langevoort, 2001). On the other hand, firm may minimise its obligation to update the reported disclosure by reducing the initial information voluntarily disclosed (Rogers \& Van Buskirk, 2009). Empirically, Brown and Tucker (2011) find that firms in a more litigious environment change their narrative reporting in MD\&A to larger degree from year to year. Therefore, the following hypothesis is set:

\section{H2c: An association exists between litigious environment and change in} FLFD.

Managerial ownership: Agency theory suggests a positive association between managerial ownership and narrative reporting because managerial ownership could serve to align interests of management with those of other shareholders (Jensen \& Meckling, 1976). Empirical literature, however, suggests results that contradict with agency theory. For instance, prior studies (e.g., Barakat \& Hussainey, 2013) find a negative association between managerial ownership and voluntary disclosure. In particular, literature reports negative association between FLFD and managerial ownership (Hussainey \& Al-Najjar, 2011; Wang $\&$ Hussainey, 2013). Based on the agency theory, firms with higher managerial ownership are more likely to change their FLFD over years to provide informative disclosure to their investors. Therefore, the following hypothesis is set:

\section{H2d: A positive association exists between managerial ownership and change in FLFD.}

Auditor type: Healy and Palepu (2001) suggest that hiring high quality auditors is a mean for a company to distinguish itself from others. High quality auditors can play an important role in improving firms' overall reporting (Hail, 2002). The Companies Act 1985 requires auditors to state whether the information given in the OFR for the financial year for which the annual accounts are prepared is consistent with those accounts, and whether any matters have come to their attention in the performance of their functions as auditors of the company, 
which in their opinion are inconsistent with the information given in the OFR. Hence, large auditors may influence managers to provide more informative disclosure in OFR statements. Therefore, our hypothesis is:

\section{H2e: A positive association exists between auditor type and change in FLFD.}

\subsubsection{Investors' response to change in FLFD}

The informativeness of FLFD is still under research (Wang \& Hussainey, 2013). OFR statements are an important venue for investors to know more about the company from the eyes of the board of directors, and through which managers can communicate what cannot be delivered by financial statements numbers. The change in FLFD is, thus, expected to be useful as it reveals considerable new information for investors.

On the other hand, managers have flexibility in how and what information to disclose, therefore, they may use their disclosure discretion to mislead investors (Marquardt \& Wiedman, 2005). Li (2008) concludes that managers can use their discretion in preparing narrative reporting to strategically obfuscate the financial results. Likewise, Athanasakou and Hussainey (2014) argue that managers use future-oriented information when they have incentives to provide untruthful disclosure and mislead investors. If so, even if managers update their discussion according to change in firm performance, investors will not have a clear view of the business and, therefore, their response to FLFD in OFR statements may be faint. Furthermore, the doubt about the usefulness of OFR statements can arise from the relative lack of the timeliness of an annual report. Even if FLFD is changed in good faith and managers provide clear analysis regarding business performance, the information is likely to be forestalled by other disclosure media.

Investors' response to change in FLFD is measured by future firm value. Generally, better information environment is associated with higher market valuation (Lang, Lins, \& Miller, 2004). High-quality disclosure enhances investors' perceptions of firms; in turn, such perceptions are reflected in firm value (Healy, Hutton, \& Palepu, 1999). Finance theory suggests that disclosure can affect firm value either by affecting its cost of capital or/and its expected cash flow (Hassan, Romilly, Giorgioni, \& Power, 2009). The empirical evidence regarding the influence of disclosure on firm value is still inclusive. Some studies maintain that narrative disclosure adds to firm value (e.g., Cheung, Jiang, \& Tan, 2010; Elzahar, 
Hussainey, Mazzi, \& Tsalavoutas, 2015), while, others (e.g., Hassan et al., 2009) do not find evidence to support this assumption. Obviously, the association between change in FLFD and firm value has not been investigated in prior research.

Based on finance theory, an investor's decision to buy or hold a company's financial securities depends on his or her expectations regarding its future cash flow. The investor expectation is based on exploiting all available information. The information released as a result of change in FLFD over years may help investors to build their expectations about future cash flows and, thus, affects firm value. Therefore, we hypothesise that

\section{H3: An association exists between the change in FLFD and firm value.}

\section{RESEARCH DESIGN}

\subsection{Measuring change in FLFD}

The automated content analysis technique is employed, and sentence is used as the unit of the analysis. To measure the change in FLFD, the following four steps are followed.

First, forward-looking sentences are extracted from OFR statements based on a list of 33 forward-looking keywords. Appendix 1 details the list of keywords. Besides, conjugations are used with verbs that imply future to reduce the likelihood of capturing noun forms of some verbs (such as "the company plans to ...."). Furthermore, numerical reference to future years is added (e.g., 2008/2009 is made when searching in the OFR statements of 2007). Second, financial-related sentences are extracted from OFR statements based on a list of financial-related keywords. Appendix 1, also, details the list of the financial-related keywords

Third, using the QSR N6 software, we search OFR statements for sentences that include both a forward-looking keyword and a financial-related keyword. This helps in counting the frequency of FLFD in a firm's OFR statements each year. Finally, the change in FLFD, $\triangle F L F D$, is equal to $F L F D$ in period ${ }_{t}$ minus $F L F D$ in period ${ }_{t-1}$. This measures the extent to which FLFD in two successive OFR documents are different. A higher score indicates more changes from the previous year and vice versa. 
To assess the reliability of the change score, a randomly selected sample from OFR statements is manually coded, and change score is calculated based on the manual coding. Following Hussianey et al. (2003), the Pearson correlation is used to compare between the change score from manual coding and the change score from automated coding. A Pearson correlation shows that the change score based on manual coding is significantly correlated with the change score from automated coding. This suggests that the change score calculated based on computer software is reliable.

Following Botosan (1997) and Brown and Tucker (2011), the current study validates the disclosure change measure by analysing the association between change score and some firm characteristics that are identified in prior research as determinates of voluntary disclosure. Further, as reported in the empirical analysis in section 4.2.1, the study finds associations between change score and firm characteristics (e.g., firm size, competitive environment, litigious environment, \& percentage of managerial ownership). This adds validity to the idea that change in the level of disclosure captures new information.

\subsection{Empirical models}

To test $\mathrm{H} 1$ and $\mathrm{H} 2$, the study controls for some economic environment variables that are identified as determinants of FLFD in prior research. Changes in these variables reveal relatively new information for managers to disclose which, in turn, affects managers' decision to change FLFD. These variables include: leverage, dividend, liquidity, and market risk exposure. Besides, we control for overall change in the length of the narrative document using change in its total statements. Finally, FLFD may be changed from the previous year because of the implementation of new narrative reporting requirements and accounting standards. Therefore, the year-fixed effect is used to control for change in FLFD due to this reason. Equation (1) summarises the empirical model. Table (1) elaborates the definitions and measurements of variables

$$
\begin{aligned}
|\Delta F L F D|= & \beta_{0}+\beta_{1}|\Delta R O E|+\beta_{2} \text { LnMK }+\beta_{3} \text { Herf }+\beta_{4} \text { Litig }+\beta_{5} \% M O+ \\
& \beta_{6} \text { BigN }+\beta_{7}|\Delta L e v|+\beta_{8}|\Delta D Y|+\beta_{9}|\Delta C R|+\beta_{10} \mid \Delta R e t . \text { Vol } \mid+ \\
& \beta_{11} \mid \Delta T . \text { Stat } \mid+ \text { Year Fixed Effect }+\varepsilon
\end{aligned}
$$

Where:

$$
\begin{array}{ll}
\boldsymbol{\beta}_{\mathbf{0}} & \text { The regression intercept } \\
\boldsymbol{\beta}_{\mathbf{1}} \ldots . \boldsymbol{\beta}_{\mathbf{1 1}} & \text { The regression coefficients } \\
\boldsymbol{\varepsilon} & \text { The error term }
\end{array}
$$


To test $\mathrm{H} 3$, we calculate the value of the firm at three months of the annual report date. This procedure ensures that stock prices capture the new information released by change in FLFD (Hassan et al., 2009). The value of the firm is measured using the natural logarithm of firm Tobin's $\mathrm{Q}$ ratio and refers to this variable as $\mathrm{LnTQ}_{+3}$. In the multivariate analysis, we control for variables that may affect firm value. These variables include: firm size, current earnings, leverage, dividends, liquidity, firm growth, capital expenditures, and managerial ownership. Besides, we use the industry-fixed effect to control for industry-specific characteristics that may affect firm value. Equation (2) summarises the empirical model. Table (2) elaborates the definitions and measurements of variables

$$
\begin{aligned}
\text { LnTQ }_{+3}= & \beta_{0} \\
+ & \beta_{1}|\Delta F L F D|+\beta_{2} L n M K+\beta_{3} R O E+\beta_{4} L e v+\beta_{5} D Y+\beta_{6} C R \\
& +\beta_{7} \text { GRTH }+\beta_{8} \text { CAPEX }+\beta_{9} \% M O+\text { Year Fixed Effect } \\
& + \text { Industry Fixed Effect }+\varepsilon
\end{aligned}
$$

Where:

$$
\begin{array}{ll}
\boldsymbol{\beta}_{\mathbf{0}} & \text { The regression intercept } \\
\boldsymbol{\beta}_{\mathbf{1}} \ldots \boldsymbol{\beta}_{\mathbf{9}} & \text { The regression coefficients } \\
\boldsymbol{\varepsilon} & \text { The error term }
\end{array}
$$

Insert Table (2) about here

The study estimates models (1) \& (2) using Ordinary Least Square (OLS) regression with clustered robust standard errors. This method allows standard errors to be clustered by firms to account for any residual dependence created by firm effects. The clustered standard error is used to mitigate the problem of time series dependence (auto-correlation). Petersen (2009) shows that this estimation method yields unbiased standard errors and, consequently, would improve the accuracy of the analyses. In addition, the study uses the year-fixed effect to address the effect of cross-sectional dependence or time effects (heteroskedasticity). We do not cluster by years in the analyses because the panel data set is short in the time series and clustering by six years may only add noise to the system (Petersen, 2009). To mitigate the 
effect of outliers, all continuous variables are winsorised at the $1^{\text {st }}$ and $99^{\text {th }}$ percentile. All change variables are winsorised before taking the absolute value.

\subsection{Sample selection and data collection}

This study examines change in FLFD in OFR statements of the FTSE all-shares firms listed on the London Stock Exchange. The sample covers annual reports for fiscal years 20052011. It starts with 2005 because the reporting standard RS1 on OFR was issued in $2005^{1}$ and ends the analysis with 2011; the most recent annual reports available at the time of the analysis. Following prior research (e.g., Elshandidy, Fraser, \& Hussainey, 2013; Elzahar et al., 2015), financial firms are excluded. In addition, we exclude observations 1) whose annual reports for the current or the previous year are missing, 2) whose annual reports cannot be converted into text file to be readable by QSR N6 software, 3) whose return on equity ratios for the current year or the previous year are missing, and 4) that changed the month of year-end during the period. This leaves us with 1,912 firm-year observations. Table (3) displays the final sample sorted by industries.

\section{Insert Table (3) about here}

Annual reports are read to identify OFR statements. When identifying OFR statements we find that there is a rarely definitive section entitled OFR. Table (4) presents different titles that report OFR contents ${ }^{2}$.

\section{Insert Table (4) about here}

Annual reports are collected from companies' official websites, the Thomson one banker database and the Northcote website (www.northcote.co.uk). All financial data is collected form Datastream. Auditor type data is manually collected from the companies' annual reports.

\footnotetext{
${ }^{1}$ On 28 November 2005, the mandatory requirement for OFR was cancelled. RS1 has been withdrawn, and the ASB has converted RS1 into a Reporting Statement of best practice on the OFR, which is considered voluntary rather than mandatory. On 1 October 2007, Business Review requirements came into effect. Recently, an entity may apply the Management Commentary practice statements from December 2010. Obviously, the Business Review and Management Commentary require companies to provide broadly the same information on narrative matters as the earlier OFR.

${ }^{2}$ This is consistent with the survey conducted by the ASB in 2009. The survey concludes that companies are titling their narrative reporting sections using a variety of names, such as Business Review, OFR, or Performance Review, as well as, the Chairman's and Chief Executive's Reviews (ASB, 2009).
} 


\section{FINDINGS}

\subsection{Descriptive statistics}

Panel A (B) of Table (5) shows the descriptive statistics of continuous variables (the frequencies for dummy variables). The maximum value of $|\triangle F L F D|$ of the sampled firms is 58 , while, the minimum is 0 . This indicates that a variation exists between UK firms in terms of their decision to change FLFD from year to year. The sample firms have, on average, change score from the previous year of 4.202.

The maximum value of $|\triangle R O E|$ is 23.17 , while, the minimum is 0.01 . This suggests significant variation between UK firms in terms of their earnings performance. On average, the sampled firms have year-over-year change in performance of 9.394. The maximum value of $L n T Q_{+3}$ of the sampled firms is 0.894 , while, the minimum is -0.823 . This indicates that a variation exists between UK firms in terms of their values.

\section{Insert Table (5) about here}

The Pearson correlation matrix, not tabulated, provides an evidence that change in FLFD is statistically correlated positively with change in firm performance $(\mathrm{p}<0.01)$. In addition, change in FLFD is significantly associated with all other explanatory variables except for $\mid \Delta$ Ret.Vol|. Some of these significant associations, especially firm size (LnMK), competitive environment (Herf), litigious environment (Litig), and percentage of managerial ownership (\%MO) are consistent with prior research (e.g., Brown \& Tucker, 2011), which add to the validity of our change measure. Furthermore, the Pearson correlation, not tabulated, indicates that the future firm value $\left(\mathrm{LnTQ}_{+3}\right)$ is not statistically correlated with change in FLFD. However, it is statistically correlated with all other explanatory variables.

We, also, calculate the Variance Inflation Factor (VIF) after carrying out each regression model to check for multicolinearity problem. If the VIF value is more than 10, this suggests multicollinearity (Field, 2009). The mean and maximum values of VIF tests are tabulated with the regression results and indicate that there is no concern about this problem. 


\subsection{Multivariate analysis}

\subsubsection{Change in FLFD and change in firm performance}

Table (6) reports the multivariate results which are robust to heteroskedasticity and autocorrelation. Columns (1) \& (2) provide the estimation of model (1) in two different ways. Column (1) uses the absolute values of change in earnings performance. This estimation preserves the magnitude of change in earnings performance. Column (2) uses the quartile ranking of absolute change in earnings performance with 1 being the smallest absolute change group and 4 being the largest absolute change group. This approach allows us to examine whether firms with larger changes in earnings performance change their FLFD more than those with smaller performance changes. Furthermore, this approach mitigates the influences of extreme values and relaxes the OLS linearity assumption (Brown \& Tucker, 2011). Because of these advantages, column (2) is treated as the primary analysis. The $t$-Statistics presented in parentheses are based on standard error clustered by firms.

The model in columns (1) \& (2) is statistically significant $(\mathrm{P}<.01)$ and the adjusted Rsquared values are $14.51 \%$ and $13.99 \%$, respectively. These values imply a good overall model fit which suggest that the model explains some variation in $|\triangle F L F D|$.

In column (1), the coefficient of $|\Delta \mathrm{ROE}|$ is 0.0017 and is statistically significant $(t=4.26)$. This means that $|\triangle F L F D|$ is positively associated with $|\Delta R O E|$. In column (2), the coefficient of $|\Delta R O E|$ is 0.1809 , and is statistically significant at $10 \%$ level of significance $(t=1.71)$. This indicates that firms with larger changes in their earnings performance change their FLFD more than those with smaller performance changes. The results suggest that firms change their FLFD in response to changes in their earnings performance. In addition, firms with larger changes in their earnings performance are likely to change their FLFD more than those with smaller performance changes. Therefore, H1a and H1b are accepted.

These results are consistent with the managers' incentive theories and empirical research. Managers' incentive theories suggest that managers with new information relative to the prior year are more likely to disclose it voluntarily to reduce both information asymmetry and agency costs. The results, also, are consistent with prior empirical research that suggests that change in disclosure is associated with change in firm performance (e.g., Lang \& Lundholm, 1993; Miller, 2002; Merkley, 2014). Furthermore, they are consistent with Brown and Tucker (2011) who find that firms with larger changes in their economic 
environment variables tend to change their narratives in MD\&A more than those with smaller changes in their economic environment.

Obviously, there is a weak statistical significance level $(\mathrm{t}=1.71)$ that firms with larger changes in their earnings performance are likely to change their FLFD more than those with smaller performance changes. This may be due to the qualitative soft talk nature FLFD. This nature may encourage managers to use the previous year's FLFD as templates without making extremely significant changes, which, in turn, reduces the variation of change in FLFD.

\section{Insert Table (6) about here}

In this part, changes in firms' earnings performance are held constant to examine the factors associated with change in FLFD. As mentioned before, column (2) is treated as the primary analysis.

Consistent with $\mathrm{H} 2 \mathrm{a}$, the coefficient on $\operatorname{LnMK}$ is 0.2938 and is statistically significant $(\mathrm{t}=$ 2.95). This suggests that larger firms change their FLFD to a greater degree than smaller firms. This may be because large firms are under pressure to disclose value relevant information to their investors (signalling theory), or to avoid political costs of being perceived as disclosing boilerplate statements. In addition, small firms are more likely to cut and paste narratives from previous years to save preparation costs.

The coefficient on Herf is 46.2672 and is statistically significant $(\mathrm{t}=2.57)$. This suggests that firms facing more competition are less likely to change their FLFD. Therefore, H2b is accepted. This is consistent with the proprietary cost of disclosure expectation and prior empirical research (e.g., Brown \& Tucker, 2011). Moreover, the coefficient on Litig is -.7629 and is statistically significant $(\mathrm{t}=-2.04)$, indicating that firms in more litigious environment are less likely to change their FLFD. Thus, H2c is accepted. This result is consistent with the theoretical expectation of litigation costs of disclosure. The results on both competitive and litigious environments suggest that firms facing more costs of disclosure are less likely to provide informative narrative reporting.

The coefficient on \%MO is -1.4811 and is statistically significant $(\mathrm{t}=-2.21)$. This indicates a negative association between percentage of managerial ownership and change in FLFD. However, this result is statistically significant; $\mathrm{H} 2 \mathrm{~d}$ is rejected due to the direction of the result. The result is not consistent with agency theory; however, it is consistent with prior 
studies (e.g., Wang \& Hussainey, 2013; Hussainey \& Al-Najjar, 2011). Furthermore, the coefficient on BigN is .337 and is not statistically significant $(\mathrm{t}=1.21)$, meaning that no relationship exists between auditor type and change in FLFD. Therefore, H2e is rejected. This result suggests that the role of the auditor in overseeing FLFD is limited. This may be because the ASB enforcement actions on auditors are small. Besides, the qualitative nature of FLFD in the UK narratives makes it difficult to be audited.

In sum, by holding changes in firm current earnings performance constant, the study finds that change in FLFD is positively (negatively) associated with firm size, (competitive environment), (litigious environment), and (percentage of managerial ownership). This result adds more validity to the change score.

In terms of economic environment control variables, the coefficient on $|\triangle D Y|$ is .2514 and is statistically significant at $10 \%$ level of significance $(\mathrm{t}=1.72)$. The result suggests that firms change their FLFD in response to changes in their dividends. This is consistent with managers' incentive theories. As well, the coefficient on $\mid \Delta T$.Stat. $\mid$ is .0018 and is statistically significant $(\mathrm{t}=2.28)$. This suggests that firms change their FLFD as long as they change the length of their narrative document from year to year. On the other hand, the coefficients on $|\Delta L e v|,|\Delta C R|$, and $|\Delta R e t . V o l|$ are $.0066(\mathrm{t}=0.74), 0042(\mathrm{t}=.03)$, and 1.0224 $(t=1.11)$, respectively. These results indicate that change in FLFD is not affected by changes in firm leverage, liquidity and business risk.

\subsubsection{Investors' response to change in FLFD}

Panel A of Table (7) reports the multivariate results of model (2) where the estimation is robust to heteroskedasticity and auto-correlation. The model is statistically significant $(\mathrm{P}<.01)$ and adjusted R- squared is $36.53 \%$. These values imply a good overall model fit which explains some variation in firm value. The $t$-Statistics presented in parentheses are based on standard error clustered by firm.

The coefficient of $\mathrm{LnTQ}_{+3}$ on $|\Delta \mathrm{FLFD}|$ is -.0059 and is statistically significant $(\mathrm{t}=-2.16)$. This indicates that $\mathrm{LnTQ}_{+3}$ is negatively associated with $|\Delta \mathrm{FLFD}|$. The result suggests that the future value of a firm decreases as it changes its FLFD from the previous year. Because the main objective of the current study is not the direction of the relation, but, the existence of such association between firm value and change in FLFD, the H3 hypothesis is accepted that an association exists between change in FLFD and firm value. 
The result is consistent with finance theory, which suggests that an investor's decision to buy or hold firm financial securities depends on his/ her expectations regarding its future cash flow. The investor's expectation is based on exploiting all available information. The information released as a result of change in FLFD from the previous year may help investors to build their expectations about the required rate of return. Consequently, this affects the future value of the firm. However, this result is not consistent with prior research (e.g., Cheung et al., 2010: Elzahar et al., 2015) who finds that narrative disclosure adds to firm value. The further analysis, in section 5, may provide more understanding of such association.

\section{Insert Table (7) about here}

In terms of the control variables, the coefficient on firm size (LnMK) and firm current earnings performance $(\mathrm{ROE})$ is $.0871(\mathrm{t}=7.09)$ and $.0110(\mathrm{t}=7.49)$, respectively. This suggests that larger firms and firms with higher earnings are more likely to exhibit higher values in the future. This is consistent with prior research (e.g., Hassan et al., 2009). Moreover, the coefficient on DY is $-.0350(\mathrm{t}=-4.36)$, suggesting that firms with higher dividends payments are less likely to have higher values in the future. This is consistent with Officer (2011) who finds that firms with lower values have significantly more positive dividend initiation announcement than other firms.

Furthermore, the coefficient on firm liquidity $(\mathrm{CR})$ is $.0859(\mathrm{t}=3.08)$ suggesting that firms with higher liquidity exhibit higher values in the future. Similarly, the coefficients on firm growth $($ GRTH) and capital expenditure $($ CAPEX) are $.0034(\mathrm{t}=2.13)$ and $.0095(\mathrm{t}=2.33)$, respectively. These results indicate that firms with higher growth and higher capital expenditures are more likely to have higher values in the future. Finally, the coefficients for future firm value on managerial ownership (\%MO) and leverage (Lev) are non-significant.

\section{FURTHER ANALYSIS}

\subsection{Well-performing and poorly performing firms}

In this section, we examine whether the association between change in FLFD and change in earnings performance differ based on the sign of earnings change. Then, we examine whether change in FLFD can affect the value of firms with earnings increase and decrease differently. To this end, the sample is divided into two subsamples: well-performing and 
poorly performing firms based on the direction of change in ROE. Firms with positive change in $\mathrm{ROE}$ from the previous year $(\triangle \mathrm{ROE}>0)$ are regarded as well-performing firms, while, firms with negative change in $\mathrm{ROE}(\triangle \mathrm{ROE}<0)$ are considered poorly performing firms.

Columns (1) \& (2) of Table (8) provide estimation of model (1) for samples of wellperforming and poorly performing firms, respectively. While, the coefficient on $|\Delta R O E|$ for well-performing firms is .0008 and is statistically significant at the $10 \%$ level of significance $(\mathrm{t}=1.73)$, the coefficient on $|\Delta \mathrm{ROE}|$ for poorly performing firms is .0025 and is statistically significant at the $1 \%$ level of significance $(t=5.94)$. This result indicates that a positive association exists between change in earnings performance and change in FLFD for both well-performing and poorly performing firms. However, this association is more positive and statistically significant for poorly performing firms compared to well-performing firms.

These results may be rationalised from two perspectives. First, managers of well-performing firms feel that their investors are satisfied with their good performance and, consequently, they would not wish for more information (Wallace \& Naser, 1995). Second, managers of poorly performing firms react to bad earnings performance by increasing discussions on activities with potential positive effect on future performance (Merkley, 2014). This suggests that poorly performing firms are more likely to provide informative narrative disclosure than well-performing firms.

Consistently, prior empirical research in the UK finds that forward-looking information is more likely to be used by un-profitable firms than by profitable firms (Hussainey \& AlNajjar, 2011; Wang \& Hussainey, 2013). In addition, Schleicher et al. (2007) find that lossmaking firms provide more relevant forward-looking information to their investors than profit-making firms.

\section{Insert Table (8) about here}

In terms of the impact on the future firm value, Panel B of Table (7) reports the estimation of model (2) for samples of well-performing and poorly performing firms separately in columns (1) \& (2), respectively. For well- performing firms, the coefficient on $|\triangle F L F D|$ is .0040 and is not statistically significant $(\mathrm{t}=-1.26)$, suggesting that the change in FLFD has no effect on the value of well-performing firms. This may be due to the lack of the timeliness of the annual reports. 
Concerning poorly performing firms, the coefficient on $|\Delta \mathrm{FLFD}|$ is -.0074 and is statistically significant $(\mathrm{t}=-2.26)$. This result suggests that the values of poorly performing firms decrease as long as these firms change their FLFD from year to year. This negative effect could be explained from two different angles. First, managers may use their discretion in preparing narrative disclosure to strategically obfuscate the financial results - that is actually poor - and this may be perceived as a way of misleading investors about an actual firm performance. Consequently, investors respond negatively to disclosure. Second, information could cause noise to investors (Cheng, Su, \& Zhu, 2012). Therefore, it may negatively affect the value of the firm.

\subsection{Robustness test}

This section presents a sensitivity analysis test to assess the robustness of the results on the usefulness of change in FLFD. One of the concerns of Tobin's Q as a measure of a firm value is that it widely varies from industry to another (Abdullah \& Page, 2009). Therefore, an alternative measure of firm value is used to test the robustness of the results.

The study computes an industry median adjusted Tobin's Q for each year. This Tobin's Q controls for potential bias arising from industry (Bebchuk, Cohen, \& Ferrell, 2009), and rules out the potential for simultaneity (Brown \& Caylor, 2006). In addition, it helps to mitigate endogeneity. The industry-median adjusted Tobin's Q is computed as a firm Tobin's Q minus the median Tobin's Q in the firm industry in the observation year.

Model (2) is re-estimated using the industry median adjusted Tobin's Q as dependent variable. Results are similar to those shown in Table 7.

\section{CONCLUSION}

This study is the first in the UK to examine to what extent FLFD is changed in response to changes in performance. In addition, it investigates the effect of such change in FLFD on the future value of a firm. The results suggest an association between change in firms' earnings performance and change in FLFD. In addition, firms with larger change in earnings performance are likely to change FLFD more than those with smaller performance changes. Further, when we distinguish between well and poorly performing firms, the study finds that poorly performing firms are likely to change FLFD more than well-performing firms. This 
suggests that poorly performing firms provide more informative disclosure to their investors than well-performing firms. Furthermore, the results indicate that change in FLFD neither affects the future value of well-performing firms, nor enhances the investors' valuation of the poorly performing firm. Therefore, FLFD in UK narratives is not really informative.

The study has implications for the emphasis in the UK regulatory bodies (e.g., IASB) on setting clear best practise guidance for narrative reporting. In the UK, managers have flexibility in terms of the amounts and contents of narrative disclosure. This room of discretion may encourage managers to strategically obscure the financial results in their narrative discussion. In this case, narratives are a mean for managers to mislead investors. Thus, guidance has to be set for managers, while, preparing their narrative discussions.

Furthermore, the results have important implications for users of annual report narratives. The importance of the narrative discussion and analysis in the annual report depends concomitantly on firm performance. In the UK, this narrative discussion is not currently subject to external audit or assurance. The results suggest that users of annual reports may desire some element of assurance that this narrative discussion is consistent with firm performance. The external auditors may be able and willing to provide such assurance.

The study, despite of the robustness tests, has some limitations which have to be considered as potential avenues for future research. First, the change score employed in the current study is based on the idea that a company will disclose considerable new information as long as it changes its level of disclosure. However, a firm may keep its FLFD level the same over years, but disclose relatively new information. Perhaps for this reason, it would be an interesting area for future research to look for other sophisticated measures of change in narrative disclosure. However, our measure is not perfect; it is one step forward in understanding managers' narrative disclosure behaviour. Second, the study uses only two proxies for governance that are managerial ownership and auditor type. It would be interesting to consider other corporate governance mechanisms in future research. 


\section{References}

Abdullah, A., \& Page, M. (2009). Corporate governance and corporate performance: UK FTSE 350 companies. Edinburgh: The Institute of Charter Accountants of Scotland.

ASB (2005). Reporting Standard (RS 1): The Operating and Financial Review, Reporting Standard. London: ASB Publications.

ASB (2006). Reporting Statement: The Operating and Financial Review, Reporting Statement. London: ASB Publications.

ASB (2009). A review of narrative reporting by UK listed companies in 2008/2009. London: ASB Publications.

Athanasakou, V., \& Hussainey, K. (2014). The perceived credibility of forward-looking performance disclosures. Accounting and Business Research, 44 (3): 227-259.

Barakat, A., \& Hussainey, K. (2013). Bank governance, regulation, supervision, and risk reporting: Evidence from operational risk disclosures in European banks. International Review of Financial Analysis, 30: 254-273.

Bebchuk, L.A, Cohen, A., \& Ferrell, A. (2009). What matters in corporate governance? The Review of Financial Studies, 22 (2): 783-727.

Beyer, A., Cohen, D.A., Lys, T.Z., \& Walther, B.R. (2010). The financial reporting environment: Review of the recent literature. Journal of Accounting and Economics, 50 (23): 296-343.

Botosan, C. (1997). Disclosure level and the cost of capital. The Accounting Review, 72: 323-350.

Botosan, C., \& Stanford, M. (2005). Managers' motives to withhold segment disclosures and the effect of SFAS No. 131 on analysts' information environment. The Accounting Review, 80 (3): 751-771. 
Brown, L. D., \& Caylor, M. L. (2006). Corporate governance and firm valuation. Journal of Accounting and Public Policy, 25 (4): 409-434.

Brown, S., \& Tucker, J. (2011). Large-sample evidence on firms' year-over-year MD\&A modifications. Journal of Accounting Research, 49 (2): 309-345.

Cheung, Y. Jiang, P., \& Tan, W. (2010). A transparency disclosure index measuring disclosures:Chinese listed companies. Journal of Accounting and Public Policy, 293: 259280 .

Cheng, P., Su, L., \& Zhu, X. (2012). Managerial ownership, board monitoring and firm performance in a family-concentrated corporate environment. Accounting and Finance, 52: $1061-1081$.

Cox, J., Hillman, \& Langevoort, D. (2001). Securities Regulation: Cases and Materials. Third ed, Aspen Publisher, New York.

Elshandidy, T., Fraser, I., \& Hussainey, K. (2013). Aggregated, voluntary, and mandatory risk disclosure incentives: Evidence from UK FTSE all-share companies. International Review of Financial Analysis, 30: 320-333.

Elzahar, H., Hussainey, K., Mazzi, F., \& Tsalavoutas, I. (2015). Economic consequences of key performance indicators' disclosure quality. International Review of Financial Analysis, forthcoming.

Feldman, R., Govindaraj, S., Livnat, J., \& Segal, B. (2010). Management's tone change, post earnings announcement drift and accruals. Review of Accounting Studies, 15: 915-953.

Field, A. (2009). Discovering Statistics using SPSS. Sage. London.

Gow, I., Ormazabal, G., \& Taylor, D. (2010). Correcting for cross-sectional and time-series dependence in accounting research. The Accounting Review, 85 (2): 483-512.

Hail, L. (2002). The impact of voluntary corporate disclosures on the ex-ante cost of capital for Swiss firms. European Accounting Review, 11 (4): 741-773.

Hassan, O., Romilly, P., Giorgioni, G., \& Power, D. (2009). The value relevance of disclosure: Evidence from the emerging capital market of Egypt. The International Journal of Accounting, 44: 79-102.

Hayn, C. (1995). The information content of losses. Journal of Accounting and Economics, 202: $125-153$.

Healy, P., \& Palepu, K. (2001). Information asymmetry, corporate disclosure, and the capital markets: A review of the empirical disclosure literature. Journal of Accounting and Economics, 31: 405-440. 
Healy, P.M., Hutton, A., \& Palepu, K.G. (1999). Stock performance and intermediation changes surrounding sustained increases in disclosure. Contemporary Accounting Research, 16 (3): 485-520.

Hussainey, K., \& Al-Najjar, B. (2011). Future-oriented narrative reporting: determinants and use. Journal of Applied Accounting Research, 12 (2):123-138.

Hussainey, K., Schleicher, T., \& Walker, M. (2003). Undertaking large-scale disclosure studies when AIMR-FAF ratings are not available: The case of prices leading earnings. Accounting and Business Research, 33 (4): 275-294.

Iatridis, G. (2008). Accounting disclosure and firms' financial attributes: Evidence from the UK stock market. International Review of Financial Analysis, 17: 219-241.

IFRS (2010). Practice statement, MC, A framework for presentation. International Financial Reporting Standard, London: UK.

Jensen, M.C., \& Meckling, W.H. (1976). Theory of the firm: management behaviour, agency costs and ownership structure. Journal of Financial Economics, 3 (3): 305-360.

Lang, M., \& Lundholm, R. (1993). Cross-sectional determinants of analyst ratings of corporate disclosures. Journal of Accounting Research, 31 (Autumn): 246-271.

Lang, M.H., Lins, K.V., \& Miller, D.P. (2004). Concentrated control, analyst following, and valuation: do analysts matter most when investors are protected least? Journal of Accounting Research, 42 (3): 589-623.

Li, F. (2008). Annual report readability, current earnings, and earnings persistence. Journal of Accounting and Economics, 45 (2-3): 221-247.

Li, F. (2010a). The Information content of forward-looking statements in corporate filingsA nave Bayesian machine learning approach. Journal of Accounting Research, 48 (5):10491102.

Li, F. (2010b). Textual analysis of corporate disclosure: A survey of the literature. Journal of Accounting Literature, 29: 143-165.

Lowry, M. (2009). Discussion of shareholders litigation and change in disclosure behaviour. Journal of Accounting and Economics, 47: 157-159

Marquardt, C., \& Wiedman, C. (2005). Earnings management through transaction structuring: Contingent convertible debt and diluted earnings per share. Journal of Accounting Research, 43: 205-243.

Merkley, K. (2014). Narrative disclosure and earnings performance: Evidence from R\&D. Accounting Review, 89 (2): 725-757.

Miller, G. (2002). Earnings performance and discretionary disclosure. Journal of Accounting Research, 40: 173-204. 
Miller, G., \& Piotroski, J. (2002). Forward-looking earnings statements: Determinants and market response. Working Paper, Harvard Business School and University of Chicago.

Muslu, V., Radhakrishnan, S., Subramanyam, K. R., \& Lim, D. (2011). Firm's information environment and forward-looking disclosures in the MD\&A. Working Paper, University of Texas at Dallas, University of Southern, California.

Officer, M. (2011). Overinvestment, corporate governance, and dividend initiations. Journal of Corporate Finance, 17 (3): 710-724.

Petersen, M. A. (2009). Estimating standard errors in finance panel data sets: Comparing approaches. Review of Financial Studies, 22: 435-479.

Radebaugh, L. H., \& Gray, S. J. (1997). International accounting and multinational enterprises. Fourth Edition, John Wiley \& Sons, Inc, New York, US.

Rogers J., \& Van Buskirk A. (2009). Shareholder litigation and changes in disclosure behaviour. Journal of Accounting and Economics, 47: 136-156.

Schleicher, T. Hussainey, K., \& Walker, M. (2007). Loss firms' annual report narratives and share price anticipation of earnings. The British Accounting Review, 39 (2):153-171.

Verrecchia, R. E. (1983). Discretionary disclosure. Journal of Accounting and Economics, 5: 365-380.

Wallace, R. S. O., \& Naser, K. (1995). Firm-specific determinants of comprehensiveness of mandatory disclosure in the corporate annual reports of firms listed on the stock exchange of Hong Kong. Journal of Accounting and Public Policy, 14 (4): 311-368.

Wang, M., \& Hussainey, K. (2013). Voluntary forward-looking statements driven by corporate governance and their value relevance. Journal of Accounting and Public Policy, 32: $26-49$.

Watts, R, L., \& Zimrman, J, L. (1978). Towards a positive theory of the determination of accounting standards. The Accounting Review, 1: 112-134. 


\section{Table 1}

Model (1) variables: Definitions and measurements

\begin{tabular}{|c|c|c|}
\hline Definition & Acronym & Operationalization \\
\hline $\begin{array}{l}\text { Change score in } \\
\text { FLFD }\end{array}$ & $|\Delta \mathrm{FLFD}|$ & Change score in FLFD as measured in section 3.1. \\
\hline Firm performance & $|\Delta \mathrm{ROE}|$ & $\begin{array}{l}\text { Year-over-year absolute change in firm return of } \\
\text { equity. Datastream code: WC } 08301 \text {. }\end{array}$ \\
\hline Firm size & LnMK & $\begin{array}{l}\text { Natural logarithm of market value of equity at the end } \\
\text { of the current year. Datastream code: WC } 08001 \text {. }\end{array}$ \\
\hline $\begin{array}{l}\text { Competitive } \\
\text { environment }\end{array}$ & Herf & $\begin{array}{l}\text { Herfendahl index measured using the } 100 \text { firms [or } \\
\text { less if the number of firms is less than 100] with the } \\
\text { highest sales in the industry [the Industry } \\
\text { Classification Benchmark (ICB) is used for industry } \\
\text { identification]. The lower the Herf, the less } \\
\text { concentrated the industry, the higher the competition, } \\
\text { and the higher the potential proprietary costs (Botosan } \\
\& \text { Stanford, 2005). }\end{array}$ \\
\hline $\begin{array}{l}\text { Litigious } \\
\text { environment }\end{array}$ & Litig & $\begin{array}{l}\text { Industry classification measured using dummy } \\
\text { variable that is equal to } 1 \text { if the firm is in technology } \\
\text { industry and } 0 \text { otherwise. }\end{array}$ \\
\hline Auditor type & BigN & $\begin{array}{l}\text { Dummy variable that is equal to } 1 \text { if the firm is } \\
\text { audited by one of the big } 4 \text { audit firms and } 0 \\
\text { otherwise. }\end{array}$ \\
\hline $\begin{array}{l}\text { Managerial } \\
\text { ownership }\end{array}$ & $\% \mathrm{MO}$ & $\begin{array}{l}\text { The percentage of total shares held by employees, or } \\
\text { by those with a substantial position in a company that } \\
\text { provides significant voting power at an annual general } \\
\text { meeting. Datastream code: NOSHEM. }\end{array}$ \\
\hline Leverage & $|\Delta \mathrm{Lev}|$ & $\begin{array}{l}\text { Year-over-year absolute change in firm Debt to equity } \\
\text { ratio. Datastream code: WC } 08231 \text {. }\end{array}$ \\
\hline
\end{tabular}




\begin{tabular}{lll}
\hline Dividend & $|\Delta \mathrm{DY}|$ & $\begin{array}{l}\text { Year-over-year absolute change in firm dividend } \\
\text { yield at the end of the fiscal year. Datastream code: } \\
\text { WC09404. }\end{array}$ \\
Liquidity & $|\Delta \mathrm{CR}|$ & $\begin{array}{l}\text { Year-over-year absolute change in firm current ratio. } \\
\text { Datastream code: WC08106. }\end{array}$ \\
Risk exposure & $\mid \Delta$ Ret.Vol $\mid$ & $\begin{array}{l}\text { Year-over-year absolute changes in firm return } \\
\text { volatility. Datastream code: 458E. }\end{array}$ \\
Document length & $\mid \Delta \mathrm{T}$. Stat $\mid$ & $\begin{array}{l}\text { Year-over-year absolute change in the total } \\
\text { statements of firm OFR section. }\end{array}$ \\
\hline This Table provides the definitions and measurements of variables in model (1).
\end{tabular}

Table 2

Model (2) variables: Definitions and measurements

\begin{tabular}{|c|c|c|}
\hline Definition & Acronym & Operationalization \\
\hline Firm value & $\mathrm{LnTQ}_{+3}$ & $\begin{array}{l}\text { Natural logarithm of Firm Tobin's } Q \text { three months } \\
\text { after the date of annual report: Tobin's } Q=[\text { (total debt } \\
+ \text { market value of equity) / book value of total assets }] \text {. } \\
\text { The market value of equity is calculated as the number } \\
\text { of outstanding shares at the year-end multiplied by the } \\
\text { market value of the share at three months after the } \\
\text { annual report date. }\end{array}$ \\
\hline Firm size & LnMK & $\begin{array}{l}\text { Natural logarithm of market value of equity at the end } \\
\text { of the current year. Datastream code: WC } 08001 \text {. }\end{array}$ \\
\hline Current earnings & ROE & Firm return of equity. Datastream code: WC08301. \\
\hline Leverage & Lev & Debt to equity ratio. Datastream code: WC08231. \\
\hline Dividend & DY & Dividend yield ratio. Datastream code: WC09402. \\
\hline Liquidity & $\mathrm{CR}$ & Current ratio. Datastream code: WC08106. \\
\hline Firm growth & GRTH & $\begin{array}{l}\text { Firm sales growth ratio. Datastream code: } \\
\text { WC } 08633 \text {. }\end{array}$ \\
\hline Capital expenditure & CAPEX & $\begin{array}{l}\text { Capital expenditure to assets ratio. Datastream code: } \\
\text { WC } 08420 \text {. }\end{array}$ \\
\hline $\begin{array}{l}\text { Managerial } \\
\text { ownership }\end{array}$ & $\% \mathrm{MO}$ & $\begin{array}{l}\text { The percentage of total shares held by employees, or } \\
\text { by those with a substantial position in a company that } \\
\text { provides significant voting power at an annual general } \\
\text { meeting. Datastream code: NOSHEM. }\end{array}$ \\
\hline
\end{tabular}




\section{Table 3}

Distribution of the sample amongst industries

\begin{tabular}{lcc}
\hline Industry & $\mathbf{N}$ & Percentage \\
\hline Industrial & 661 & $35 \%$ \\
Basic materials & 149 & $8 \%$ \\
Technology & 191 & $10 \%$ \\
Consumer goods & 211 & $11 \%$ \\
Consumer services & 427 & $22 \%$ \\
Health care & 115 & $6 \%$ \\
Oil and gas & 100 & $5 \%$ \\
Utilities & 36 & $2 \%$ \\
Telecommunication & 22 & $1 \%$ \\
\hline Total & $\mathbf{1 , 9 1 2}$ & $\mathbf{1 0 0 \%}$ \\
\hline This Table provides the distribution of the sample among industries. The definitions of the industries are based \\
on the Industry Classification Benchmark (ICB).
\end{tabular}




\begin{tabular}{lcc}
\hline $\begin{array}{l}\text { Table } 4 \\
\text { Different titles that report OFR contents }\end{array}$ & \\
\hline & $\mathbf{N}$ & Percentage \\
\hline OFR & 293 & $15 \%$ \\
Operating review/ Financial review & 326 & $17 \%$ \\
Business review & 665 & $35 \%$ \\
Chief executive review & 535 & $28 \%$ \\
Operating review & 59 & $3 \%$ \\
Financial review & 34 & $2 \%$ \\
\hline Total & $\mathbf{1 , 9 1 2}$ & $\mathbf{1 0 0 \%}$ \\
\hline This Table reports different titles for OFR contents. Firms produce OFR statements under the title OFR; or \\
report two separate sections Operating Review and Financial Review; or produce the same OFR contents \\
under the title Business Review; or under the title Chief Executive Review; or produce either only an \\
Operating Review or a Financial Review.
\end{tabular}




\section{Table 5}

Sample descriptive statistics

\begin{tabular}{lccccc}
\hline Panel A: Continuous variables & & & & \\
\hline Variable & Obs. & Mean & Std. Dev. & Min & Max \\
\hline $\mid \Delta$ FLFD $\mid$ & 1,912 & 4.202 & 5.059 & 0.00 & 58.00 \\
$\mid \Delta$ ROE $\mid$ & 1,912 & 9.394 & 7.927 & 0.01 & 23.17 \\
LnTQ+3 & 1,912 & -0.010 & 0.545 & -0.823 & 0.894 \\
LnMK & 1,912 & 12.410 & 1.892 & 9.591 & 15.437 \\
Herf & 1,912 & 0.009 & 0.014 & 0.0002 & 0.045 \\
$\%$ MO & 1,912 & 0.087 & 0.1566 & 0.00 & 0.99 \\
ROE & 1,912 & 14.481 & 14.374 & -8.95 & 40.41 \\
Lev & 1,912 & 52.706 & 53.160 & 0.00 & 166.96 \\
DY & 1,912 & 2.653 & 2.053 & 0.00 & 6.21 \\
CR & 1,912 & 1.614 & 0.826 & 0.68 & 3.35 \\
GRTH & 1,912 & 8.752 & 10.129 & -6.86 & 26.48 \\
CAPEX & 1,912 & 5.394 & 5.109 & 0.85 & 17.23 \\
$\mid \Delta$ Lev $\mid$ & 1,912 & 15.168 & 14.698 & 0.00 & 40.4 \\
$\mid \Delta$ DY $\mid$ & 1,912 & 0.912 & 0.898 & 0.00 & 2.71 \\
$\mid \Delta$ CR $\mid$ & 1,912 & 0.223 & 0.173 & 0.001 & 0.50 \\
$\mid \Delta$ Ret.Vol $\mid$ & 1,912 & 0.196 & 0.140 & 0.00 & 0.41 \\
$\mid \Delta$ T.Stat $\mid$ & 1,912 & 135.42 & 120.443 & 6.00 & 568 \\
\hline
\end{tabular}

\begin{tabular}{lccc}
\hline \multicolumn{2}{l}{ Panel B: Dummy variables } & & \\
\hline Variable & Dummies & N & $\%$ \\
\multirow{2}{*}{ Litig } & 0 & 1,722 & $90 \%$ \\
& 1 & 191 & $10 \%$ \\
\multirow{2}{*}{ BigN } & 0 & 327 & $17 \%$ \\
& 1 & 1,586 & $83 \%$ \\
\hline
\end{tabular}

This Table provides the descriptive statistics for all variables. Panel A (B) shows the descriptive statistics of continuous variables (the frequencies for dummy variables).

Tables 1 \& 2 define all variables. 


\section{Table 6}

Model (1) results: Incentives to change FLFD

\section{(1)}

(2)

\begin{tabular}{|c|c|c|c|c|}
\hline & Variables & $\begin{array}{c}\text { Pred. } \\
\text { Sign }\end{array}$ & $\begin{array}{l}\text { Coefficient } \\
\text { (t-statistic) }\end{array}$ & $\begin{array}{l}\text { Coefficient } \\
\text { (t-statistic) }\end{array}$ \\
\hline Constant & & & $\begin{array}{l}-.4487 \\
(-0.32)\end{array}$ & $\begin{array}{c}-1.1353 \\
(-0.82)\end{array}$ \\
\hline Performance & $|\Delta \mathrm{ROE}|$ & + & $\begin{array}{c}.0017 * * * \\
(4.26)\end{array}$ & $\begin{array}{l}.1809^{*} \\
(1.71)\end{array}$ \\
\hline Size & LnMK & + & $\begin{array}{c}.2651 * * * \\
(2.64)\end{array}$ & $\begin{array}{c}.2938 * * * \\
(2.95)\end{array}$ \\
\hline $\begin{array}{l}\text { Competitive } \\
\text { environment }\end{array}$ & Herf & + & $\begin{array}{c}47.6255^{* * * *} \\
(2.64)\end{array}$ & $\begin{array}{c}46.2672 * * * \\
(2.57)\end{array}$ \\
\hline Litigious environment & Litig & $+/-$ & $\begin{array}{c}-.8120 * * \\
(-2.15)\end{array}$ & $\begin{array}{c}-.7629 * * \\
(-2.04)\end{array}$ \\
\hline Managerial ownership & $\% \mathrm{MO}$ & + & $\begin{array}{c}-1.7284 * * * \\
(-2.73)\end{array}$ & $\begin{array}{c}-1.4811 * * * \\
(-2.21)\end{array}$ \\
\hline Auditor type & BigN & + & $\begin{array}{l}.3395 \\
(1.23)\end{array}$ & $\begin{array}{l}.3370 \\
(1.21)\end{array}$ \\
\hline Leverage & $|\Delta \operatorname{Lev}|$ & + & $\begin{array}{l}.0063 \\
(0.75)\end{array}$ & $\begin{array}{c}.0066097 \\
(0.74)\end{array}$ \\
\hline Dividend & $|\Delta \mathrm{DY}|$ & + & $\begin{array}{l}.2546^{*} \\
(1.75)\end{array}$ & $\begin{array}{l}.2514^{*} \\
(1.72)\end{array}$ \\
\hline Liquidity & $|\Delta \mathrm{CR}|$ & + & $\begin{array}{l}.0194 \\
(0.13)\end{array}$ & $\begin{array}{l}.0042 \\
(0.03)\end{array}$ \\
\hline Business risk & $\mid \Delta$ Ret. Vol $\mid$ & + & $\begin{array}{l}1.1906 \\
(1.27)\end{array}$ & $\begin{array}{l}1.0224 \\
(1.11)\end{array}$ \\
\hline Document length & $\mid \Delta$ T.Stat. $\mid$ & + & $\begin{array}{c}.0017 * * \\
(2.26)\end{array}$ & $\begin{array}{c}.0018 * * \\
(2.28)\end{array}$ \\
\hline Fixed effect & & & Year & Year \\
\hline Standard error clustering & & & Firm & Firm \\
\hline Model F & & & $11.80 * * *$ & $10.74 * * *$ \\
\hline Prob $>F$ & & & 0.0000 & 0.0000 \\
\hline Adjusted R- squared & & & $14.51 \%$ & $13.99 \%$ \\
\hline
\end{tabular}


VIF: Mean

Max.

This Table reports the coefficients' estimates of model (1). Column (1) uses the absolute values of change in earnings performance, while, column (2) uses the quartile ranking of absolute change in earnings performance with 1 being the smallest absolute change group and 4 being the largest absolute change group. The $t$-Statistics in parentheses are based on robust standard error clustered by firms to control for autocorrelation and heteroskedasticity.

Table 1 defines all variables.

$*, * *$ and $* * *$ indicate significance at $0.1,0.05$, and 0.01 , respectively.

Table 7

Model (2) results : Change in FLFD impact on firm value

\begin{tabular}{|c|c|c|c|c|c|}
\hline & & & \multirow{2}{*}{$\begin{array}{c}\text { Panel A } \\
\begin{array}{c}\text { All sampled } \\
\text { firms }\end{array} \\
\end{array}$} & \multicolumn{2}{|c|}{ Panel B } \\
\hline & & & & $\begin{array}{c}(1) \\
\Delta R O E>0\end{array}$ & $\begin{array}{c}(2) \\
\Delta R O E<0\end{array}$ \\
\hline & Variables & $\begin{array}{l}\text { Pred. } \\
\text { Sign }\end{array}$ & $\begin{array}{l}\text { Coefficient } \\
\text { (t-statistic) }\end{array}$ & $\begin{array}{l}\text { Coefficient } \\
\text { (t-statistic) }\end{array}$ & $\begin{array}{l}\text { Coefficient } \\
\text { (t-statistic) }\end{array}$ \\
\hline Constant & & & $\begin{array}{c}-1.6249 * * * \\
(-6.70)\end{array}$ & $\begin{array}{c}-1.6590 * * * \\
(-7.34)\end{array}$ & $\begin{array}{c}-1.4050 * * * \\
(-6.85)\end{array}$ \\
\hline $\begin{array}{l}\text { Forward-looking } \\
\text { financial disclosure }\end{array}$ & $|\Delta \mathrm{FLFD}|$ & $+/-$ & $\begin{array}{c}-.0059 * * \\
(-2.16)\end{array}$ & $\begin{array}{l}-.0040 \\
(-1.26)\end{array}$ & $\begin{array}{c}-.0074 * * \\
(-2.26)\end{array}$ \\
\hline Firm's size & LnMK & + & $\begin{array}{c}.0871 * * * \\
(7.09)\end{array}$ & $\begin{array}{c}.0880 * * * \\
(6.05)\end{array}$ & $\begin{array}{c}.0874 * * * \\
(6.77)\end{array}$ \\
\hline Profitability & ROE & + & $\begin{array}{c}.0110 * * * \\
(7.49)\end{array}$ & $\begin{array}{c}.0120 * * * \\
(6.55)\end{array}$ & $\begin{array}{c}.0098 * * * \\
(6.39)\end{array}$ \\
\hline Leverage & Lev & $+/-$ & $\begin{array}{l}.00005 \\
(0.16)\end{array}$ & $\begin{array}{l}-.0003 \\
(-0.83)\end{array}$ & $\begin{array}{l}.0005 \\
(0.213)\end{array}$ \\
\hline Dividend & DY & $+/-$ & $\begin{array}{c}-.0350 * * * \\
(-4.36)\end{array}$ & $\begin{array}{c}-.0348 * * * \\
(-3.28)\end{array}$ & $\begin{array}{c}-.03853 * * * \\
(-4.28)\end{array}$ \\
\hline Liquidity & $\mathrm{CR}$ & + & $\begin{array}{c}.08597 * * * \\
(3.08)\end{array}$ & $\begin{array}{c}.0917 * * * \\
(2.98)\end{array}$ & $\begin{array}{c}.0837 * * * \\
(2.68)\end{array}$ \\
\hline Firm growth & GRTH & + & $\begin{array}{c}.0034 * * \\
(2.13)\end{array}$ & $\begin{array}{c}.0063^{* * * *} \\
(3.18)\end{array}$ & $\begin{array}{l}.0006 \\
(0.34)\end{array}$ \\
\hline Capital expenditures & CAPEX & + & $\begin{array}{c}.0095^{* *} \\
(2.33)\end{array}$ & $\begin{array}{l}.0068 \\
(1.45)\end{array}$ & $\begin{array}{l}.0106^{* *} \\
(2.43)\end{array}$ \\
\hline Managerial ownership & $\% \mathrm{MO}$ & $+/-$ & $\begin{array}{l}.1051 \\
(0.72)\end{array}$ & $\begin{array}{l}.0914 \\
(0.65)\end{array}$ & $\begin{array}{l}.1265 \\
(0.71)\end{array}$ \\
\hline Fixed effect & & & $\begin{array}{l}\text { Year\& } \\
\text { Industry }\end{array}$ & $\begin{array}{l}\text { Year\& } \\
\text { Industry }\end{array}$ & $\begin{array}{l}\text { Year \& } \\
\text { Industry }\end{array}$ \\
\hline Standard error clustering & & & Firm & Firm & Firm \\
\hline Model F & & & $74.42 * * *$ & $27.46^{* * *}$ & $29.56 * * *$ \\
\hline Prob $>F$ & & & .0000 & .0000 & .0000 \\
\hline Adjusted R-squared & & & $36.53 \%$ & $37.21 \%$ & $34.85 \%$ \\
\hline
\end{tabular}




\begin{tabular}{lccc}
\hline VIF: Mean & 1.33 & 1.42 & 1.46 \\
Max. & 1.49 & 1.84 & 1.92 \\
Observation (N) & 1,912 & 946 & 966 \\
\hline This Table reports the coefficients' estimates of model (2). Panel A reports the estimation for all sampled firms. \\
Whilst, panel B provides the estimation for well and poorly performing firms in columns 1 \& 2, respectively. The $t$ - \\
Statistics in parentheses are based on robust standard error clustered by firms to control for auto-correlation and \\
heteroskedasticity. \\
\hline Table 2 defines all variables \\
\hline$* * *$ and $* * *$ indicate significance at $0.1,0.05$, and 0.01, respectively \\
\hline
\end{tabular}

\section{Table 8}

Model (1) results: Well-performing and poorly performing firms

\begin{tabular}{|c|c|c|c|c|}
\hline & & & $\begin{array}{c}(1) \\
\Delta R O E>0\end{array}$ & $\begin{array}{c}(2) \\
\Delta \mathrm{ROE}<0\end{array}$ \\
\hline & Variables & $\begin{array}{c}\text { Pred. } \\
\text { Sign } \\
\end{array}$ & $\begin{array}{l}\text { Coefficient } \\
\text { (t-statistic) }\end{array}$ & $\begin{array}{l}\text { Coefficient } \\
\text { (t-statistic) }\end{array}$ \\
\hline Constant & & & $\begin{array}{c}-2.1794 \\
(-1.24)\end{array}$ & $\begin{array}{l}1.1530 \\
(0.85)\end{array}$ \\
\hline Performance & $|\Delta \mathrm{ROE}|$ & + & $\begin{array}{l}.0008^{*} \\
(1.73)\end{array}$ & $\begin{array}{c}.0025 * * * \\
(5.94)\end{array}$ \\
\hline Size & LnMK & + & $\begin{array}{c}.3347 * * \\
(2.56)\end{array}$ & $\begin{array}{l}.1715 \\
(1.48)\end{array}$ \\
\hline $\begin{array}{l}\text { Competitive } \\
\text { environment }\end{array}$ & Herf & + & $\begin{array}{c}52.4033 * * \\
(2.33)\end{array}$ & $\begin{array}{l}38.6538 * * \\
\quad(2.01)\end{array}$ \\
\hline Litigious environment & Litig & $+/-$ & $\begin{array}{l}-.9159 * \\
(-1.89)\end{array}$ & $\begin{array}{l}-.5151 \\
(-1.09)\end{array}$ \\
\hline Managerial ownership & $\% \mathrm{MO}$ & + & $\begin{array}{c}-1.8560^{*} \\
(-1.96)\end{array}$ & $\begin{array}{c}-1.4982 * * \\
(-2.01)\end{array}$ \\
\hline Auditor type & BigN & + & $\begin{array}{l}.1612 \\
(0.37)\end{array}$ & $\begin{array}{c}.6986^{* * *} \\
(2.23)\end{array}$ \\
\hline Leverage & $|\Delta \operatorname{Lev}|$ & + & $\begin{array}{l}.0136 \\
(1.15)\end{array}$ & $\begin{array}{l}-.0024 \\
(-0.20)\end{array}$ \\
\hline Dividend & $|\Delta \mathrm{DY}|$ & + & $\begin{array}{l}.3102 \\
(1.42)\end{array}$ & $\begin{array}{l}.1855 \\
(1.27)\end{array}$ \\
\hline Liquidity & $|\Delta \mathrm{CR}|$ & + & $\begin{array}{l}.1358 \\
(0.67)\end{array}$ & $\begin{array}{l}-.1175 \\
(-0.67)\end{array}$ \\
\hline Business risk & $\mid \Delta$ Ret. Vol $\mid$ & + & $\begin{array}{c}2.0645^{*} \\
(1.76)\end{array}$ & $\begin{array}{l}-.0686 \\
(-0.05)\end{array}$ \\
\hline Document length & $\mid \Delta \mathrm{T}$. Stat $\mid$ & + & $\begin{array}{l}.0011^{*} \\
(1.66)\end{array}$ & $\begin{array}{c}.0033 * * * \\
(3.08)\end{array}$ \\
\hline $\begin{array}{l}\text { Fixed effect } \\
\text { Standard error clustering }\end{array}$ & & & $\begin{array}{l}\text { Year } \\
\text { Firm }\end{array}$ & $\begin{array}{l}\text { Year } \\
\text { Firm }\end{array}$ \\
\hline Model F & & & $7.56 * * *$ & $11.03 * * *$ \\
\hline Prob $>F$ & & & 0.0000 & 0.0000 \\
\hline
\end{tabular}


Adjusted R- squared

Max.

This Table reports the coefficients' estimates of model (1) for well and poorly performing firms, separately in Columns (1) \& (2), respectively. The $t$-Statistics in parentheses are based on robust standard error clustered by firms to control for auto-correlation and heteroskedasticity.

Table 1 defines all variables.

$*, * *$, and $* * *$ indicate significance at $0.1,0.05$, and 0.01, respectively

\section{Appendix 1: List of keywords}

\begin{tabular}{|c|c|c|c|}
\hline \multicolumn{4}{|c|}{ Forward-looking keywords } \\
\hline $\begin{array}{l}\text { Aim } \\
\text { Anticipate } \\
\text { Believe } \\
\text { Coming } \\
\text { Estimate } \\
\text { Eventual } \\
\text { Expect } \\
\text { Following } \\
\text { Forecast }\end{array}$ & $\begin{array}{l}\text { Forthcoming } \\
\text { Future } \\
\text { Hope } \\
\text { Incoming } \\
\text { Intend } \\
\text { Intention } \\
\text { Likely } \\
\text { Look-ahead } \\
\text { Look-forward }\end{array}$ & $\begin{array}{l}\text { Next } \\
\text { Plan } \\
\text { Predict } \\
\text { Project } \\
\text { Prospect } \\
\text { Seek } \\
\text { Shortly } \\
\text { Soon } \\
\text { Subsequent }\end{array}$ & $\begin{array}{l}\text { Unlikely } \\
\text { Upcoming } \\
\text { Well-placed } \\
\text { Well-positioned } \\
\text { Will } \\
\text { Year-ahead }\end{array}$ \\
\hline \multicolumn{4}{|c|}{ Financial-related keywords } \\
\hline $\begin{array}{l}\text { Amortisation } \\
\text { Costs } \\
\text { Depletion } \\
\text { Depreciation } \\
\text { Discontinued } \\
\text { operations } \\
\text { Dividends } \\
\text { Earnings } \\
\text { EBI } \\
\text { EBIT } \\
\text { EBITDA } \\
\text { Expenses } \\
\text { Extraordinary items } \\
\text { Gain } \\
\text { Impairment } \\
\text { Income } \\
\text { Loss } \\
\text { Margin }\end{array}$ & $\begin{array}{l}\text { Profit } \\
\text { Revenue } \\
\text { Sales } \\
\text { Tax } \\
\text { Assets } \\
\text { Capital } \\
\text { Debt } \\
\text { Equity } \\
\text { Inventories } \\
\text { Investment property } \\
\text { Liabilities } \\
\text { Payable } \\
\text { Property plant and } \\
\text { equipment } \\
\text { Provisions } \\
\text { Receivable Cash } \\
\text { Cash flow }\end{array}$ & $\begin{array}{l}\text { Cash inflow } \\
\text { Cash outflow } \\
\text { Acid test ratio } \\
\text { Cash flow per share } \\
\text { Credit given } \\
\text { Credit obtained } \\
\text { Current ratio } \\
\text { Dividend cover } \\
\text { Dividends yield } \\
\text { Earnings per share } \\
\text { EPS } \\
\text { Gearing } \\
\text { Gross margin ratio } \\
\text { Interest cover } \\
\text { Liquidity ratio } \\
\text { Market to book value } \\
\text { ratio }\end{array}$ & $\begin{array}{l}\text { Price earnings ratio } \\
\text { Profit margin } \\
\text { Profitability } \\
\text { Quick ratio } \\
\text { Return on assets } \\
\text { Return on capital } \\
\text { employed } \\
\text { Return on equity } \\
\text { Return on investment } \\
\text { ROA } \\
\text { ROCE } \\
\text { ROE } \\
\text { Stock turnover }\end{array}$ \\
\hline
\end{tabular}


